\title{
Pengaruh Respon Penggunaan Media Game Edukasi Quizizz dalam Pembelajaran Jarak Jauh terhadap Hasil Belajar Siswa Kelas XI SMA Negeri 3 Samarinda
}

\author{
Triyana Meirlin ${ }^{1}$, Laili Komariyah ${ }^{2}$, dan Shelly Efwinda ${ }^{3}$ \\ $1^{*}$ Program Studi Pendidikan Fisika, FKIP, Universitas Mulawarman \\ Jl. M. Yamin Samarinda, Kalimantan Timur, Indonesia \\ *E-mail: triyanameirlin98@gmail.com
}

\begin{abstract}
Abstrak
Penelitian ini bertujuan untuk mengetahui pengaruh respon penggunaan media game edukasi Quizizz terhadap hasil belajar siswa. Teknik pengambilan sampel dalam penelitian ini yaitu purposive sampling dengan sampe kelas XI MIPA 1 sebanyak 36 siswa. Jenis penelitian yang digunakan adalah kuantitatif dan desain yang digunakan dalam penelitian ini adalah one-shot case study design. Pengambilan data dalam penelitian ini menggunakan tes akhir yang kemudian dianalisis menggunakan uji analisis regresi sederhana serta angket untuk mengetahui respon siswa. Hasil analisis menunjukkan bahwa nilai rata-rata hasil belajar siswa sebesar 87,92 yang termasuk dalam kriteria tinggi. Berdasarkan hasil analisis angket menunjukkan bahwa respon siswa termasuk dalam kategori baik dengan persentase sebesar $88,9 \%$. Hal ini di dukung dengan hasil uji analisis regresi linier sederhana yang memperoleh nilai signifikan 0,034 yang lebih kecil dari taraf signifikansi 0,05 sehingga terdapat pengaruh respon penggunaan media game edukasi Quizizz terhadap hasil belajar siswa di SMA Negeri 3 Samarinda.
\end{abstract}

Kata kunci: Media game edukasi quizizz, pembelajaran jarak jauh, dan hasil belajar

\section{Abstract}

This study aims to determine the effect of the response of Quizizz educational game media application to student learning outcomes. The sampling technique in this study is purposive sampling with a sample of 36 students in the class of XI MIPA 1. The type of research used is quantitative, and the design used in this study is a one-shot case study design. Data collection in this study used a final test which was then analyzed using a simple regression analysis test and a questionnaire to determine student responses. The analysis results showed that the average value of student learning outcomes is 87.92, which is included in the high criteria. The questionnaire analysis results showed that the students' responses were included in the good category with a percentage of $88.9 \%$. This is supported by the results of a simple linear regression analysis test with a significant value of 0.034 , which is smaller than the 0.05 significance level. There is an effect of the response to Quizizz educational game media application on student learning outcomes at SMA Negeri 3 Samarinda.

Keywords: Quizizz educational game media, distance learning, and learning outcomes

Article History: Received: 16 Juli 2021

Accepted: 25 November
Revised : 25 November 2021

Published: 30 November 2021

How to cite: Meirlin, T, Komariyah, L, Efwinda, S. (2021). Pengaruh Respon Penggunaan Media Game Edukasi Quizizz dalam Pembelajaran Jarak Jauh Terhadap Hasil Belajar Siswa Kelas XI SMA Negeri 3 Samarinda, Jurnal Literasi Pendidikan Fisika, 2 (2). pp. 117-125. Retrieved from http://jurnal.fkip.unmul.ac.id/index.php/JLPF

Copyright (C) November 2021, Jurnal Literasi Pendidikan Fisika 
Pengaruh Respon Penggunaan...

\section{PENDAHULUAN}

Pendidikan adalah sebuah proses pembelajaran untuk peserta didik dalam mengembangkan pengetahuan, keterampilan dan kebiasaan. Pendidikan juga merupakan suatu bentuk upaya nyata dan sistematis yang dapat membantu peserta didik dalam mengembangkan karakter lewat berbagai macam kegiatan pengembangan budi pekerti, penanaman nilai, nilai agama dan pelatihan nilai-nilai moral serta keterampilan yang berguna untuk dirinya dan masyarakat.

Pada akhir tahun 2019, dunia dilanda wabah virus yang menyebar ke seluruh dunia. World Health Organization (WHO) sebagai organisasi kesehatan dunia telah menetapkan virus Corona atau COVID19 sebagai pandemi dan merekomendasikan untuk mengurangi atau memberhentikan sementara kegiatan dan aktifitas yang berpotensi menimbulkan kerumunan besar (Wahidah et al., 2020). Pandemi COVID-19 menyebabkan dampak ke berbagai sektor kehidupan, salah satunya dalam sektor pendidikan. Siswa diberbagai penyelenggara pelayanan pendidikan, seperti sekolah di semua tingkatan, dan lembaga pendidikan non formal hingga perguruan tinggi merasakan dampak yang besar. Untuk mengatasi pandemi ini, pemerintah mengeluarkan kebijakan untuk menjaga jarak dalam interaksi sosial (social distancing), karantina mandiri, dan isolasi sehingga setiap individu yang rentan tidak akan terkena virus (Mulatsih, 2020). Ini merupakan upaya dalam rangka berpartisipasi memutus mata rantai penyebaran virus corona, maka dilakukan pembelajaran jarak jauh dan menyarankan siswa untuk belajar dari rumah masing-masing melalui media daring (online). Guru perlu memastikan bahwa kegiatan belajar mengajar tetap berjalan meskipun siswa berada di rumah. Pembelajaran dapat dilakukan dengan menggunakan metode E-learning yaitu pembelajaran memanfaatkan teknologi informasi dan komunikasi (Mulatsih, 2020). Sistem pembelajaran dilaksanakan menggunakan laptop atau perangkat komputer (PC) yang terhubung dengan internet dan guru dapat menggunakan aplikasi Zoom, grup jejaring sosial seperti Whatsapp $(W A)$, telegram ataupun media sosial lainnya sebagai media pembelajaran yang memungkinkan siswa untuk belajar di waktu yang sama meskipun di lokasi yang berbeda.

Dalam menciptakan proses pembelajaran yang berkualitas, guru terkadang mengalami kesulitan dalam menerangkan materi pembelajaran, terlebih dalam pelajaran Fisika. Guru sering melakukan percobaan pada materi yang sama dengan menggunakan media secara konvensional yaitu alat-alat percobaan di laboratorium selama proses belajar mengajar dengan cara model mengajar guru yang selalu ceramah. Maka dari itu perlu adanya hal baru yang dapat membuat siswa tertarik dan tidak cepat merasa mengantuk dan bosan, yaitu penggunaan media pembelajaran. Kemajuan teknologi saat ini sudah berkembang pesat sehingga media pembelajaran dapat dibuat mengikuti perkembangan yang ada. Penggunaan media pembelajaran dapat membantu guru dalam menyampaikan materi dan mendorong siswa lebih semangat dalam proses pembelajaran. Harus kita akui bahwa pentingnya media serta segala sesuatu yang diperlukan dalam membantu proses belajar, semakin hari dapat kita rasakan. Pengelolaan alat bantu dalam pembelajaran sangat diperlukan (Nurrita, 2018).

Quizizz merupakan salah satu bentuk game. Game sebagai media pembelajaran yang terintegrasi dengan materi atau soal - soal evaluasi dapat menjadikan proses pembelajaran menjadi lebih menarik dan menyenangkan. Salah satu dampak positif penggunaan game adalah game menimbulkan suasana menyenangkan dan menghibur serta game memberikan latihan untuk pemecahan masalah dan logika (Henry, 2010). Game Quizizz adalah aplikasi pendidikan berbasis game, yang membawa aktivitas multi permainan ke ruang kelas dan membuat latihan di kelas menjadi interaktif dan menyenangkan. Penerapan dalam penggunaan Game Quizizz, memungkinkan siswa dapat melakukan latihan di dalam kelas pada perangkat elektronik mereka. Game Quizizz memiliki karakteristik permainan seperti tema, avatar, musik dan meme yang memberi efek interaktif dan menyenangkan selama proses pembelajaran. Quizizz memotivasi siswa belajar dan memungkinkan siswa untuk saling bersaing sehingga hasil belajar bisa meningkat. Siswa mengerjakan kuis pada waktu yang sama di kelas dan dapat melihat peringkat langsung mereka di papan peringkat (Purba, 2019). 
Pengaruh Respon Penggunaan...

Dengan penggunaan media pembelajaran Quizizz peneliti berharap dapat membantu siswa memahami materi Fisika. Berdasarkan latar belakang tersebut, maka penulis tertarik untuk melakukan penelitian yang diberi judul: Pengaruh Respon Penggunaan Media Game Edukasi Quizizz dalam Pembelajaran Jarak Jauh terhadap Hasil Belajar Siswa Kelas XI SMA Negeri 3 Samarinda.

\section{METODE}

Jenis penelitian ini menggunakan metode penelitian kuantitatif. Penelitian ini untuk mengetahui pengaruh respon penggunaan media game edukasi Quizizz dalam pembelajaran jarak jauh terhadap hasil belajar siswa kelas XI SMA Negeri 3 Samarinda. Peneliti menggunakan satu kelas untuk dijadikan sebagai kelas eksperimen. Dalam penelitian ini, menggunakan desain one-shot case study, dimana tidak ada kelompok kontrol dan siswa diberi perlakuan khusus atau pengajaran selama beberapa waktu (tanda X). Subjek dalam penelitian ini akan mendapatkan perlakuan (treatment) yaitu penggunaan media game edukasi Quizizz. Kemudian di akhir program, siswa diberi tes yang terkait dengan perlakuan/pengajaran yang diberikan (tanda $O$ ) yang diberikan perlakuan (treatment) menggunakan media game edukasi Quizizz. Desain penelitian ini dapat dilihat pada Gambar 1 (Sugiyono, 2017)

Keterangan:

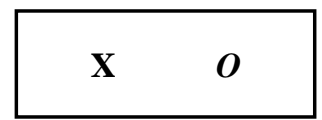

X : Perlakuan (media game edukasi Quizizz) yang diberikan

$O \quad$ : Nilai tes setelah diberi perlakuan

Gambar 1. Grafik Persentase Respon Siswa Terhadap penggunaan media game edukasi Quizizz

Teknik pengambilan sampel yang digunakan adalah purpossive sampling, yaitu teknik sampling yang digunakan oleh peneliti jika peneliti memiliki pertimbangan tertentu dalam penentuan sampel dengan tujuan tertentu (Riduwan, 2013). Teknik penentuan sampel atas dasar pertimbangan atau arahan dari guru mata pelajaran dari sekolah yang diteliti dengan kriteria siswa aktif dalam pembelajaran. Pada penelitian ini, peneliti menggunakan teknik pengumpulan data, yaitu:

1. Teknik Angket

Angket digunakan untuk mengetahui respon siswa terhadap pembelajaran dengan menggunakan media game edukasi Quizizz. Angket diberikan setelah semua kegiatan pembelajaran dan evaluasi dilakukan, berupa 12 item pernyataan dengan beberapa jawaban yang akan dipilih oleh siswa. Angket yang akan digunakan dalam penelitian ini adalah angket dengan skala Likert.

2. Teknik Tes

Tes hasil belajar dalam penelitian ini digunakan untuk mengukur hasil belajar siswa pada materi Suhu, Kalor dan Perpindahan Kalor. Tes objektif pilihan ganda diberikan kepada siswa sesudah (posttest) diajarkan materi Suhu, Kalor dan Perpindahan Kalor.

Analisis data dilakukan dengan menggunakan bantuan program SPSS 25 for Windows. Teknik untuk menganalisis data menggunakan analisis deskriptif, yaitu pengujian mean, median, dan modus untuk kategori penilaian hasil belajar siswa. Analisis angket untuk melihat respon siswa dan persentase respon siswa dihitung dengan menggunakan rumus sebagai berikut:

$$
P=\frac{f}{N} \times 100 \%
$$

Keterangan:

$\mathrm{P}=$ Persentase respon siswa

$f=$ Frekuensi siswa yang memilih

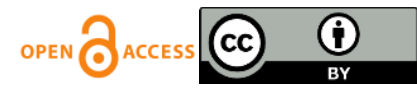


Pengaruh Respon Penggunaan...

$\mathrm{N}$ = Jumlah siswa

3. Uji Hipotesis

Pengujian hipotesis menggunakan analisis regresi linier sederhana. Analisis regresi sederhana digunakan untuk mengetahui perubahan yang terjadi pada variabel dependet (variabel $Y$ ), nilai variabel dependent berdasarkan nilai independent (variabel X) yang diketahui. Untuk mengetahui pengaruh yang diperkirakan antara Respon Penggunaan Media Game Edukasi Quizizz dengan Hasil Belajar Siswa dilakukan dengan rumus regresi linier sederhana, yaitu sebagai berikut:

$$
\hat{Y}=a+b X
$$

Keterangan:

$\hat{Y}=$ Subjek variabel terikat yang diprediksi

$\mathrm{X}=$ Subjek variabel bebas yang mempunyai nilai tertentu

$\mathrm{a}=$ Konstanta

$\mathrm{b}=$ Koefisien regresi

Data yang diuji adalah terdistribusi normal jika menunjukkan signifikansi $>0,05$, sebaliknya data yang di uji tidak terdistribusi normal jika signifikansi $<0,05$. Demikian juga dengan uji regresi untuk menguji hipotesis penelitian, terlebih dahulu kemudian diubah menjadi hipotesis yaitu :

$\mathrm{Ha}_{\mathrm{a}}$ : Terdapat pengaruh Respon Penggunaan Media Game Edukasi Quizizz dalam Pembelajaran Jarak Jauh Terhadap Hasil Belajar Siswa Kelas X SMA Negeri 3 Samarinda.

Ho: Tidak terdapat pengaruh Respon Penggunaan Media Game Edukasi Quizizz dalam Pembelajaran Jarak Jauh Terhadap Hasil Belajar Siswa Kelas X SMA Negeri 3 Samarinda.

Ketentuan :

Jika Sig $(2$-tailed $)<\alpha$, maka Ho ditolak

Jika Sig (2-tailed) $\geq \alpha$, maka Ho diterima

\section{HASIL DAN PEMBAHASAN}

\section{HASIL}

Penelitian ini dilaksanakan di SMA Negeri 3 Samarinda dari tanggal 8 Oktober hingga 5 November 2020. Adapun sampel yang diambil pada penelitian ini yaitu kelas XI MIPA 1 dengan jumlah siswa sebanyak 36 orang. Hasil dari pembelajaran materi fisika Suhu, Kalor dan Perpindahan Kalor dapat kita gunakan untuk mengetahui ada atau tidaknya pengaruh Respon Penggunaan Media Game Edukasi Quizizz terhadap Hasil Belajar siswa di SMAN 3 Samarinda.

1. Analisis Data Angket Respon Siswa

Respon siswa terhadap kegiatan pembelajaran dengan menggunakan Media Game Edukasi Quizizz diketahui melalui angket dalam bentuk 12 pernyataan dengan indikator yang sudah ditetapkan yang dikumpulkan di akhir kegiatan pembelajaran. Hasil analisis skor angket respon penggunaan Media Game Edukasi Quizizz dapat dilihat dengan persentase yang disajikan pada Tabel 1.

Tabel 1. Persentase Respon siswa Terhadap penggunaan media game edukasi Quizizz

\begin{tabular}{llcc}
\hline Nilai & Kategori & Frekuensi & Persentase \\
\hline $1,00 \leq x \geq 1,59$ & Sangat Kurang & 0 & $0 \%$ \\
\hline $1,60 \leq x \geq 2,19$ & Kurang & 0 & $0 \%$ \\
\hline $2,20 \leq x \geq 2.79$ & Cukup & 4 & $11.1 \%$ \\
\hline $2,80 \leq x \geq 3,39$ & Baik & 32 & $88.9 \%$ \\
\hline $3,40 \leq x \geq 4,00$ & Sangat Baik & 0 & $0 \%$ \\
\hline
\end{tabular}


Pengaruh Respon Penggunaan...

Jika disajikan dalam bentuk grafik, persentase skor kategori penggunaan media game edukasi Quizizz dapat digambarkan seperti pada Gambar 2. Berdasarkan Gambar 2, hasil analisis angket respon siswa terhadap penggunaan media game edukasi Quizizz menunjukkan sebagian besar siswa memberikan respon yang baik. Respon siswa berada pada kategori cukup hingga baik masing-masing sebanyak $11,1 \%$, dan $88,9 \%$.

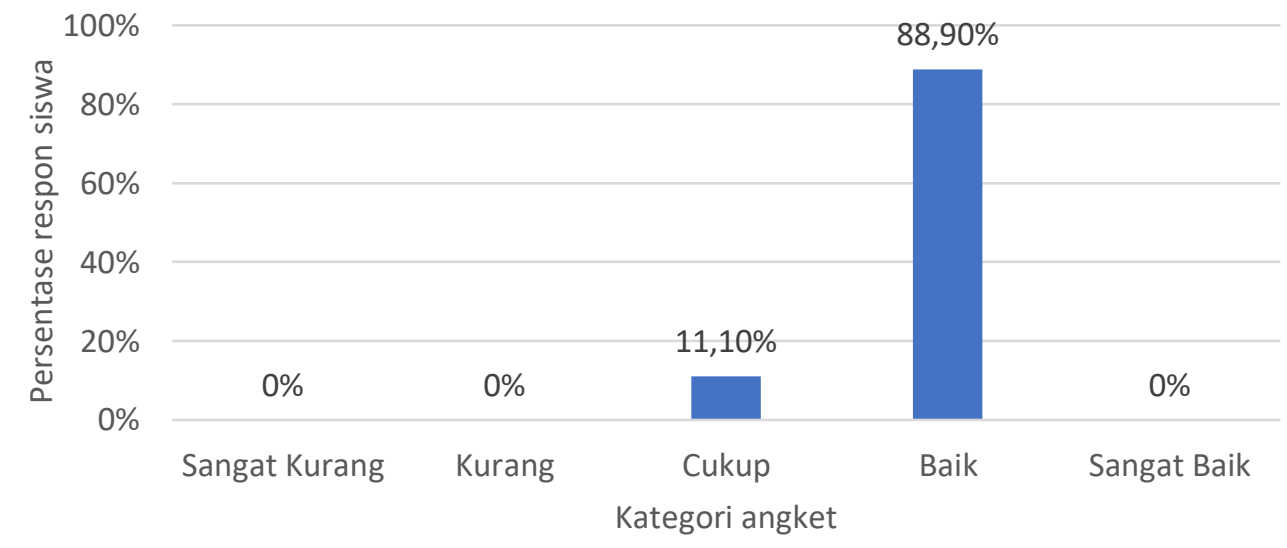

Gambar 2. Grafik Persentase Respon Siswa Terhadap penggunaan media game edukasi Quizizz

\section{Analisis Deskriptif Hasil Belajar Siswa}

Hasil belajar siswa diukur menggunakan nilai posttest setelah diberi perlakuan dengan penggunaan media game edukasi Quizizz selama pembelajaran jarak jauh. Nilai posttest yang diperoleh dari 36 siswa mempunyai nilai tertinggi 100,00 dan nilai terendah 60,00. Distribusi frekuensi hasil belajar siswa ditunjukkan dalam Tabel 2.

Tabel 2. Distribusi frekuensi data hasil belajar siswa

\begin{tabular}{|c|c|c|c|c|c|}
\hline \multicolumn{6}{|c|}{ Hasil Belajar Siswa } \\
\hline & & Frequency & Percent & Valid Percent & Cumulative Percent \\
\hline \multirow[t]{9}{*}{ Valid } & 60.00 & 1 & 2.8 & 2.8 & 2.8 \\
\hline & 65.00 & 3 & 8.3 & 8.3 & 11.1 \\
\hline & 75.00 & 2 & 5.6 & 5.6 & 16.7 \\
\hline & 80.00 & 4 & 11.1 & 11.1 & 27.8 \\
\hline & 85.00 & 5 & 13.9 & 13.9 & 41.7 \\
\hline & 90.00 & 4 & 11.1 & 11.1 & 52.8 \\
\hline & 95.00 & 9 & 25.0 & 25.0 & 77.8 \\
\hline & 100.00 & 8 & 22.2 & 22.2 & 100.0 \\
\hline & Total & 36 & 100.0 & 100.0 & \\
\hline
\end{tabular}

Jika disajikan dalam bentuk grafik, distribusi frekuensi data hasil belajar siswa dapat digambarkan seperti pada Gambar 3. Berdasarkan Gambar 3, persentase distribusi frekuensi data hasil belajar siswa diketahui siswa yang mendapat nilai $60,65,75,80,85,90,95$ dan 100 masing-masing sebanyak 2,8\%; $8,3 \% ; 5,6 \% ; 11,1 \% ; 13,9 \% ; 11,1 \% ; 25 \%$ dan $22,2 \%$. Persentase paling sedikit berada pada nilai 60 dan persentase tertinggi pada nilai 95 . 
Pengaruh Respon Penggunaan...

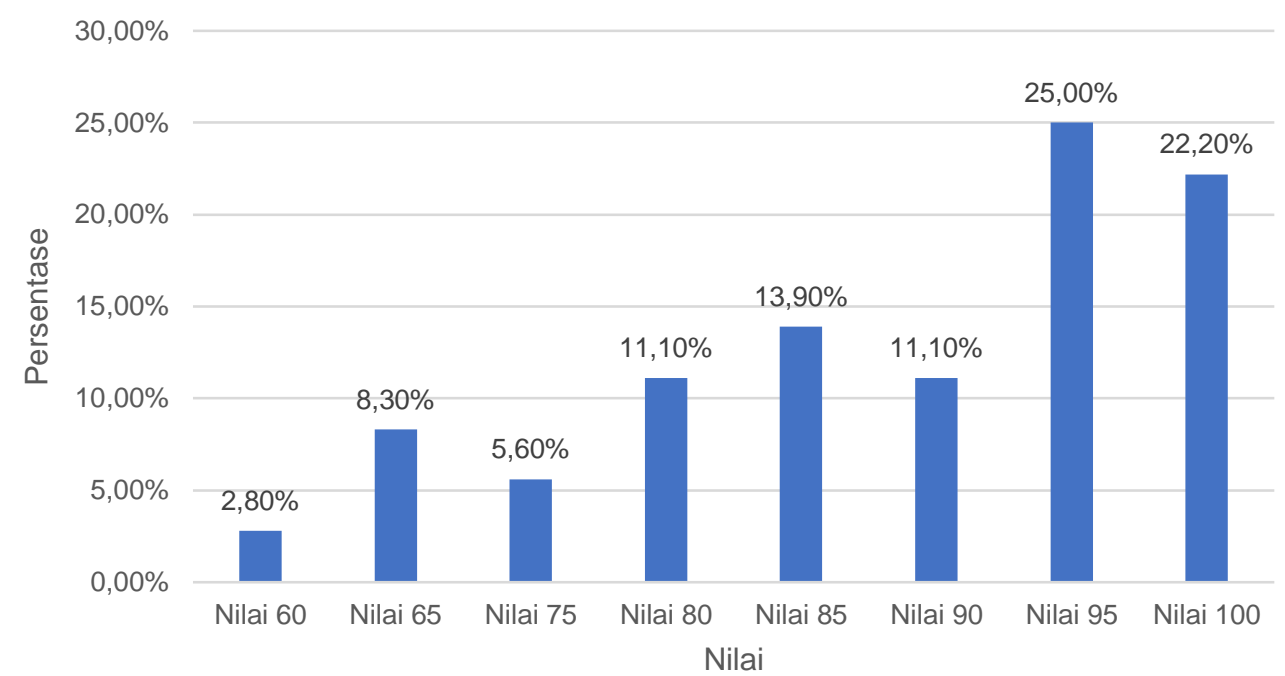

Gambar 3. Grafik Persentase distribusi frekuensi data hasil belajar siswa

3. Pengujian Hipotesis

Untuk pengujian hipotesis menggunakan analisis regresi linier sederhana. Tabel 3 menunjukkan hasil analisis regresi linier sederhana dengan bantuan SPSS 25.0.

Tabel 3. Output Ketiga dari Uji Analisis Regresi Linier Sederhana SPSS 25.0

\begin{tabular}{llrrrrr}
\hline \multicolumn{7}{c}{ ANOVA $^{\mathbf{a}}$} \\
\hline 1 & Model & Sum of Squares & Df & Mean Square & F & Sig. \\
\hline 1 & 581.287 & 1 & 581.287 & 4.895 & $.034^{b}$ \\
\cline { 2 - 7 } & Regression & 4037.463 & 34 & 118.749 & & \\
\cline { 2 - 7 } & Residual & 35 & & & \\
\hline
\end{tabular}

a. Dependent Variable: Hasil Belajar Siswa

b. Predictors: (Constant), Respon Penggunaan Media Game Edukasi Quizizz

Dari tabel diatas dapat diketahui bahwa nilai $\mathrm{F}$ hitung $=4,895$ dengan tingkat signifikansinya sebesar $0,03<0,05$, maka Ha diterima dan Ho ditolak, karena itu dapat disimpulkan bahwa model regresi ini, yaitu respon penggunaan media game edukasi Quizizz mempengaruhi hasil belajar siswa. Tidak hanya itu, hasil ini juga menunjukkan bahwa respon penggunaan media game edukasi Quizizz dengan proses hasil belajar siswa mempunyai hubungan linear.

\section{PEMBAHASAN}

Tujuan penelitian ini yaitu untuk mengetahui respon siswa terhadap penggunaan media game edukasi Quizizz kemudian untuk mengetahui frekuensi data hasil belajar siswa dengan penggunaan media game edukasi Quizizz dalam pembelajaran dan untuk mengetahui pengaruh dari respon penggunaan media game edukasi Quizizz terhadap hasil belajar siswa. Penelitian ini dilakukan secara eksperimen yang merupakan salah satu jenis penelitian yang digunakan untuk mencari perlakuan tertentu terhadap yang lain dalam kondisi terkendalikan. Pada saat melakukan penelitian terdapat sebanyak empat kali pertemuan, yaitu dengan tiga kali pertemuan pembelajaran dan satu kali pertemuan untuk posttest. Pada sampel kelas diberi perlakuan berupa pembelajaran dengan menggunakan media game edukasi Quizizz dan zoom sebagai pengganti pembelajaran tatap muka di kelas atau sarana pembelajaran jarak jauh (PJJ). Pembelajaran jarak jauh diterapkan dikarenakan

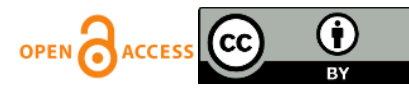


Pengaruh Respon Penggunaan...

situasi akibat mewabahnya covid-19. Meskipun tidak melakukan pembelajaran secara langsung di sekolah, pembelajaran tatap muka dapat dilakukan secara online. Dengan adanya situasi darurat seperti inilah penggunaan media game edukasi Quizizz menjadi pilihan dalam proses pembelajaran, karena dapat membuat siswa dapat aktif. Posttest dilaksanakan selama 2 jam pembelajaran (90 menit), sedangkan total waktu untuk kegiatan belajar mengajar dilakukan selama 6 jam pembelajaran $(6 \times 45$ menit).

Berdasarkan data yang diperoleh untuk mengetahui tentang respon siswa terhadap media game edukasi Quizizz, peneliti menggunakan angket yang diberikan setelah proses pembelajaran selesai dimana respon siswa yang ingin diketahui meliputi indikator penggunaan media game edukasi Quizizz dalam proses pembelajaran, penyajian materi suhu, kalor dan perpindahan kalor pada pembahasan soal, penggunaan animasi pada media game edukasi Quizizz dan penjelasan rumus dalam media game edukasi Quizizz. Data yang diperoleh menunjukkan seluruh siswa memberikan respon cukup hingga baik terhadap penggunaan media game edukasi Quizizz yang diterapkan pada materi suhu, kalor dan perpindahan kalor. Respon siswa berada pada kategori cukup hingga baik masing-masing sebanyak $11,1 \%$, dan $88,9 \%$. Hasil skor tertinggi yang diperoleh dari angket respon siswa adalah 3,33. Hal ini menunjukkan siswa memiliki ketertarikan yang tinggi terhadap penggunaan media game edukasi Quizizz dan dapat memahami materi fisika dengan baik melalui penggunaan media game edukasi Quizizz. Terdapat perbedaan yang cukup jauh antara skor tertinggi dan skor terendah hasil angket respon siswa. Skor terendah yang diperoleh salah satu siswa yaitu 2,25. Hal ini menunjukkan siswa memberikan respon yang kurang terhadap penggunaan media pembelajaran. Siswa tersebut kurang maksimal dalam mengikuti pembelajaran dikarenakan sering tidak hadir dan tidak aktif dalam pembelajaran, sehingga tidak mengikuti materi pembelajaran dari awal.

Dari hasil data yang diperoleh untuk mengetahui hasil belajar siswa dengan penggunaan media game edukasi Quizizz, peneliti melakukan test akhir (posttest) kepada siswa. Nilai rata-rata posttest siswa sebesar 87,92 dengan nilai maksimum sebesar 100. Berdasarkan Gambar 3, persentase distribusi frekuensi data hasil belajar siswa diketahui siswa yang mendapat nilai $60,65,75,80,85,90$, 95 dan 100 masing-masing sebanyak 2,8\%; 8,3\%; 5,6\%; 11,1\%; 13,9\%; 11,1\%; 25\% dan 22,2\%. Persentase paling sedikit berada pada nilai 60 dan persentase tertinggi pada nilai 95 . Hal ini menunjukkan bahwa penggunaan media game edukasi Quizizz dapat mempengaruhi hasil belajar siswa. Tabel 2 menunjukkan distribusi frekuensi nilai hasil belajar posttest siswa. Sebanyak 4 siswa mendapat nilai di bawah KKM. Hal tersebut terjadi karena siswa tidak aktif dalam proses pembelajaran dan sering tidak hadir. Sebagian besar siswa lainnya mendapat nilai tinggi di atas KKM. Hal ini menunjukkan penggunaan media game edukasi Quizizz memiliki dampak positif terhadap hasil belajar siswa.

Dalam penelitian ini untuk mengetahui pengaruh dari respon penggunaan media game edukasi Quizizz terhadap hasil belajar siswa analisis data penelitian ini menggunakan uji regresi linier sederhana. Hasil uji hipotesis berdasarkan Tabel 3 memperoleh nilai signifikan 0.034 yang lebih kecil dari taraf signifikansi 0.05 , sehingga kesimpulan yang diperoleh adalah hipotesis awal $\left(\mathrm{H}_{0}\right)$ ditolak dan hipotesis alternatif $\left(\mathrm{H}_{\mathrm{a}}\right)$ diterima. Sehingga diketahui bahwa respon penggunaan media game edukasi Quizizz mempengaruhi hasil belajar siswa pada materi suhu, kalor dan perpindahan kalor. Hal ini sejalan dengan penelitian yang dilakukan oleh Zhao (2019), yang berjudul "Using Quizizz to Integrate Fun Multiplayer in The Accounting Classroom", yang dimuat dalam International Journal of Higher Education, 8(1). Hasil penelitian ini yaitu dengan menggunakan Quizizz meningkatkan pengalaman belajar siswa, selain itu siswa yang menggunakan Quizizz memberikan skor evaluasi yang lebih tinggi dan Quizizz memberikan dampak positif pada keterlibatan siswa dan hasil belajar siswa di kelas akuntansi. Kemudian penelitian yang dilakukan oleh Grinias (2017), berjudul "Making a Game Out of It: Using Web-Based Competitive Quizezz for Quantitative Analysis Content Review", yang dimuat dalam Journal of Chemical Education. Hasil dari penelitian ini adalah penggunaan game berbasis kuis kompetitif berbasis web memanfaatkan sistem respon siswa untuk meninjau ujian komprehensif, selain 
Pengaruh Respon Penggunaan...

itu membantu dan menyenangkan siswa dalam kelas kimia analisis kuantitatif serta penelitian yang dilakukan oleh Latifah (2019), yang berjudul "Pengaruh Penggunaan Media Kuis Interaktif Berbantu Quizizz Terhadap Hasil Belajar Matematika Peserta Didik". Hasil penelitian ini menunjukkan penggunaan Quizizz memberikan dampak positif pada keterlibatan siswa (respon siswa) dan hasil belajar siswa

Dengan adanya respon siswa dan daya saing yang tinggi siswa akan belajar lebih giat untuk mendapatkan hasil prestasi belajar yang memuaskan pada saat posttest. Hal ini didukung dengan hasil posttest yang diperoleh siswa dimana nilai rata-rata posttest sebesar 87,92 yang termasuk dalam kategori tinggi. Penggunaan media game edukasi Quizizz ini memberikan dampak positif pada keterlibatan siswa serta nilai yang diperoleh siswa. Berdasarkan hal tersebut, maka ada keterhubungan antara respon siswa, penggunaan media game edukasi Quizizz serta hasil belajar siswa. Dalam penelitian ini adapun kendala-kendala yang dihadapi saat menggunakan media game edukasi Quizizz adalah fokus siswa pada saat mengerjakan soal di media game edukasi Quizizz kurang maksimal, jaringan internet yang kurang stabil

\section{PENUTUP}

Berdasarkan penelitian dan analisis data yang telah dilakukan, maka dapat ditarik kesimpulan bahwa respon siswa terhadap penggunaan media game edukasi Quizizz di SMA Negeri 3 Samarinda termasuk dalam kategori baik dengan persentase sebesar $88,9 \%$ kemudian hasil belajar siswa di SMA Negeri 3 Samarinda pada materi suhu, kalor dan perpindahan kalor dengan penggunaan media game edukasi Quizizz diperoleh rata-rata nilai sebesar 87,92 dan masuk ke dalam kategori tinggi dan terdapat pengaruh respon penggunaan media game edukasi Quizizz terhadap hasil belajar siswa pada materi suhu, kalor dan perpindahan kalor di SMA Negeri 3 Samarinda. Hal ini didasarkan pada hasil perhitungan uji analisis regresi linier sederhana yang memperoleh nilai signifikan 0,034 yang lebih kecil dari taraf signifikansi 0,05.

Adapun saran yang dapat diberikan berdasarkan penelitian yang telah dilakukan yaitu hasil belajar siswa dapat ditingkatkan lagi dengan penggunaan media game edukasi Quizizz jika melakukan pembelajaran tatap muka di kelas, tidak hanya melalui aplikasi zoom dan bila media ini diterapkan secara terus-menerus. Penggunaan media game edukasi Quizizz dapat dijadikan alternatif pilihan pada strategi pembelajaran fisika untuk memberikan dampak positif hasil belajar siswa, membuat proses pembelajaran lebih aktif serta meningkatkan kemandirian belajar dan kemampuan siswa dalam memperoleh pengetahuan maupun informasi dari berbagai sumber. Dikarenakan penggunaan media game edukasi Quizizz membutuhkan jaringan internet yang baik, maka penelitian ini tidak disarankan bagi sekolah/siswa yang berada di daerah pelosok kecuali memang sudah tersedia jaringan wi-fi (internet) yang cukup baik dan stabil.

\section{DAFTAR PUSTAKA}

Grinias, J. P. (2017). Making a Game out of It: Using Web-Based Competitive Quizzes for Quantitative Analysis Content Review. Journal of Chemical Education, 94(9), 1363-1366. https://doi.org/10.1021/acs.jchemed.7b00311

Henry, S. (2010). Cerdas dengan Game. PT Gramedia Pustaka Utama.

Latifah, I. N. (2019). Pengaruh Penggunaan Media Kuis Interaktif Berbantu Aplikasi Quizizz Terhadap Hasil Belajar Matematika Peserta Didik. Institut Agama Islam Negeri Syekh Nurjati Cirebon, 369(1), 1689-1699. https://doi.org/10.1017/CBO9781107415324.004

Mulatsih, B. (2020). Penerapan Aplikasi Google Classroom , Google Form , Dan Quizizz Dalam Pembelajaran Kimia Di Masa Pandemi Covid-19 Application of Google Classroom , Google Form and Quizizz in Chemical Learning During the Covid-19 Pandemic. Ideguru: Jurnal Karya IImiah Guru, 5(1), 16-26.

Nurrita, T. (2018). Pengembangan Media Pembelajaran Untuk Meningkatkan Hasil Belajar Siswa. 
Pengaruh Respon Penggunaan...

Misykat, 03(1), 171-187.

Purba, L. S. L. (2019). Peningkatan Konsentrasi Belajar Mahasiswa Melalui Pemanfaatan Evaluasi Pembelajaran Quizizz Pada Mata Kuliah Kimia Fisika I. Jurnal Dinamika Pendidikan, 12(1), 29. https://doi.org/10.33541/jdp.v12i1.1028

Riduwan. (2013). Dasar-Dasar Statistika (11th ed.). Alfabeta.

Sugiyono. (2017). Metode Penelitian Kuantitatif, Kualitatif dan R\&D. Alfabeta.

Wahidah, I., Athallah, R., Hartono, N. F. S., Rafqie, M. C. A., \& Septiadi, M. A. (2020). Pandemik COVID-19: Analisis Perencanaan Pemerintah dan Masyarakat dalam Berbagai Upaya Pencegahan. Jurnal Manajemen Dan Organisasi, 11(3), 179-188. https://doi.org/10.29244/jmo.v11i3.31695

Zhao, F. (2019). Using Quizizz to Integrate Fun Multiplayer Activity in The Accounting Classroom. International Journal of Higher Education, 8(1), 37-43. https://doi.org/10.5430/ijhe.v8n1p37 